Roman Tytarenko, Roman Khmil, Iryna Dankevych

\title{
THEORETICAL ANALYSIS OF EXISTING CONCEPTS TO EVALUATE THE NON-FAILURE OF RC STRUCTURES IN OPERATION
}

\author{
Department of Building Constructions and Bridges, \\ Lviv Polytechnic National University \\ romantaren27@gmail.com
}

CC Tytarenko R., Khmil R., Dankevych I., 2021

\begin{abstract}
The article presents a theoretical analysis of existing concepts to evaluate the non-failure of RC structures in operation. To perform the analysis, the authors considered a number of scientific works of both Ukrainian and foreign researchers. The main focus was on works in which the model of the stochastic nature of the RC structure operation included random parameters of acting loads, as well as the reserve of its bearing capacity and serviceability (geometric dimensions of cross sections of constructive members, strength and deformation characteristics of materials, etc.). Among others, according to the authors, important problems in terms of analysis of a single work were the volume of statistical selection of random parameters, their number and impact on the study result, as well as rationality of the adopted method of calculating the probability of failure (or non-failure work) of $\mathrm{RC}$ structure in operation. Based on the processing of a number of scientific works, the authors highlight the relevance, advantages and disadvantages of the concepts of non-failure assessment proposed there, as well as the formulate the conclusions and recommendations for further experimental and theoretical research in this area.

Keywords: non-failure assessment, probability of non-failure work, reinforced concrete, structure acting load, random parameter, statistical selection, numerical simulation, calculation method, Monte Carlo method.
\end{abstract}

\section{Introduction}

Reliability is the main measure of the quality of structural members and systems in general. The introduction of the concept of reliability in national (System for ensuring the reliability and safety of building objects, DBN, 2018) and foreign (Basis of structural design, Eurocode, 2002; General principles on reliability for structures, ISO, 2015) building codes provided a single criterion for RC structures design (based on the use of the apparatus of probability theory and mathematical statistics) and identified the direction of improving existing calculation methods, focused on improving safety. In turn, probabilistic analysis of non-failure, as a basic characteristic of reliability, is now an extremely important and relevant scientific and technical problem both in Ukraine and in the world, as it guarantees the non-approach of limit state of a particular structure with a certain probability - the probability of non-failure work. Thus, having previously set the required (minimum) probability of non-failure-work (or failure probability), possible to determine the cross-sectional dimensions (or the reinforcement percentage) of the constructive member, corresponding to the specified probabilities.

The design of any building structures always takes place under uncertain conditions: geometric dimensions, strength and deformation characteristics of materials, acting loads and impacts are random variables (or functions). Today, the reliability of RC structures in the design is ensured by calculation by 
the semi-probabilistic deterministic method of limit states (Concrete and reinforced concrete structures, DBN, 2011), because in the existing probabilistic (stochastic) calculation methods (including non-failure assessing) there is no single objective criterion for calculation due to insufficient regulatory base, which currently has an auxiliary (recommendatory) character (at present, most of the random parameters acting loads, operating conditions, bearing capacity reserve and serviceability of structures - are not fully investigated and require a much larger volume of the statistical selection).

Based on the above, as well as the adaptation of national standards for the RC structures design (Concrete and reinforced concrete structures made of heavy concrete, DSTU, 2011), in terms of their application in the reliability theory (probabilistic calculation methods), it becomes obvious: the topicality of the problem of developing of such a methodology for assessing the non-failure of RC structures, which makes it possible to take into account the complete picture of the stochastic nature of their work, is undeniable. Moreover, based on the review of recent studies of the stress-strain state of RC structures with damages (Voskobiinyk, 2010; Klymenko, Antoniuk \& Polianskyi, 2019), under the action of an aggressive environment (Faye, 2017; Khaghanpour, Dousti \& Shekarchi, 2017; Chen, Sun, Hu \& Shi, 2021), taking into account the influence of RC nonlinear work (Sakhno, Lyulchenko, Yanova \& Pyshchykova, 2020) or its rheological properties (Bashynska, 2019; Heraskin, Rotko \& Uzhehova, 2020), as well as actual climatic loads (Pashinsky, 2015) - there is a need to develop their stochastic models.

\section{The article target}

The article target is a theoretical analysis of existing concepts to evaluate the non-failure of RC structures in operation, as well as the formation of actual tasks and recommendations for future experimental and theoretical research in this area.

\section{The problem of regulatory support}

As of today, the general principles of ensuring the reliability (including the non-failure) and structural safety of both buildings and structures as a whole and their single constructive members are of a recommendatory (formal) nature, and are described in national norms (System for ensuring the reliability and safety of building objects, DBN, 2018) and European standards (Basis of structural design, Eurocode, 2002; General principles on reliability for structures, ISO, 2015). The main disadvantages of all these regulatory documents are the following: 1) there is no clear methodology for assessing the reliability of structures in operation (incompleteness of mathematical apparatuses for probabilistic calculations with minimal error); 2) there is no algorithm for determining the variation coefficients of those or others stochastic variables of working capacity functions (most of the variation coefficients, described in handbooks, are outdated and need to be updated through new studies, as well as collection, processing and synthesis of statistics - especially in terms of actual climatic loads, taking into account corrosion and mechanical damages of structures, as well as the RC rheological properties); 3) there are no clear recommendations regarding use, in one case or another, of the distribution law of random variables of the working capacity function and the method of calculating the structure failure.

The world today is extremely turbulent. Over the last 20 years, despite a certain decrease in reliability problem interest, a number of Ukrainian and foreign scientists have made a significant contribution to the development of reliability theory in general and methods of reliability assessment in particular. Below we will focus on the analysis of studies, which, in our opinion, most fully and systematically reflect the trends in the development of concepts for assessing the non-failure of RC structures in operation.

\section{Recent studies: existing concepts to evaluate the non-failure}

To solve the problem of developing statistical approaches of the risk evaluation of corrosion initiation due to chloride ingress, the authors (Kiesse, Bonnet, Amiri \& Ventura, 2020) used sensitivity analysis to identify the influence of input parameters on critical length of time before corrosion initiation 
predicted by developed chloride diffusion model. In this work exceedance probabilities of corrosion initiation time given that input parameters exceed certain thresholds were also calculated. The article results showed that the corrosion initiation time was most sensitive to: 1) chloride effective diffusion coefficient in concrete (that is a parameter controllable by relevant stakeholders); 2) surface chloride concentration (that is a non-controllable parameter depending on surrounding conditions). And if reducing the chloride diffusion coefficient (controllable parameter) enables to postpone the maintenance of structures (as analyzed in the article), then, in turn, the interaction between controllable parameters and noncontrollable surrounding conditions was also revealed here, influential on the results reliability (the article disadvantage). Among the article undeniable advantages, in our opinion, are the following: 1) the accordance of input parameters (including the technological parameter of the position of steel rebar in concrete) to the European Union norms; 2) parameters statistics related to the materials property (chloride diffusion, porosity) was calculated on the basis of a large number of experimental data.

The work (Pellizzer, Leonel \& Nogueira, 2015), which is of great practical importance, was devoted to studying the mechanical effects of reinforcement corrosion in hyperstatic RC beams. The research results showed that reinforcement corrosion changes the failure scenarios modes of hyperstatic $\mathrm{RC}$ beams. Therefore, as the article authors emphasize, unimportant failure modes in the design phase become important after corrosion start. The work advantages, we think, are the following: 1) the focus is the probabilistic determination of individual failure scenarios change as well as global failure change over time; 2) the applied limit state functions analytically describe for both bending and shear resistance of beams cross-sections as a function of steel and concrete resistance, and section dimensions (Fick's law here also models the chloride penetration into concrete pores); 3) the high precision Monte Carlo simulation method was used, which, in turn, assesses each single failure probability. Among the article insignificant disadvantages, in our opinion, are the following: 1) serviceability limit states were not counted in this study; 2) only hyperstatic continuous two-span beams of rectangular cross-section (the same type) were considered; 3 ) the evaluation of RC members strength, considering simple bending and shear cases, was performed based on classical hypotheses and models according to only the Brazilian standard (was accepted the plastic depth simplification, allowed by the parabolic-rectangle diagram for compression concrete (given here by $y=0.8 x$ ), which, in turn, is also a random variable and depends on many factors); 4) most of the parameters accepted here in the probabilistic analysis (except for the random parameters for both concrete and steel strength, as well as permanent and accidental loads) are deterministic (including important parameters of water-cement ratio, chloride concentration for reinforcement depassivation, and on the beam surface, as well as the chloride diffusion coefficient in concrete).

In the works (Bastidas-Arteaga, Bressolette, Chateauneuf \& Sanchez-Silva, 2009; Conciatori, Bruhwiler \& Morgenthaler, 2009) were presented, accordingly: 1) the reliability analysis of bridge girders located in various chloride-contaminated environments (based on a proposed new model to evaluate the lifetime of RC structures, subject to corrosion-fatigue deterioration processes); 2) the developed example using a nonlinear transport model to simulate the chloride ion penetration into $\mathrm{RC}$ and to predict the development of corrosion in the structure (based on the use of the Rosenblueth method for stochastic parameters analyzing in a numerical model). Despite the systematic nature of the material presented, as well as the results validity in both papers, including that the coupled effect of corrosion fatigue on RC structures strongly affects their performance, leading to a significant reduction in the expected lifetime (the $1^{\text {st }}$ case) or that the chloride ion exposure degree affects in a dominating way the apparition of structural damage (the $2^{\text {nd }}$ case), they have such disadvantages as use for the reliability analysis only bridge girders structure (the $1^{\text {st }}$ case) or use to analyze stochastic parameters in a numerical model the simplified Rosenblueth method (the $2^{\text {nd }}$ case).

The article (Krasnoshchekov \& Zapoleva, 2015) is devoted to studying the problem of the probabilistic design of structures by the given level of reliability. The calculation model of a random safety factor is proposed here, as well as the example of RC slab calculating for a given reliability is developed. The problem of this work is that it is used here the two-moments method (or the statistical linearization 
method) doesn't fully reflect the real picture of the stochastic nature of the RC structures work (not all random parameters of materials strength, their deformability, or actual loads can be described by the normal distribution law) and can only be used for approximate reliability assessment.

In both articles (Khmil, Tytarenko, Blikharskyy \& Vegera, 2021), the authors, based on the probabilities theory fundamental principles (Ventsel, 2018), presented the new probabilistic calculation models of RC beams, strengthened under load (accordingly, by tensile steel reinforcement increasing and $\mathrm{RC}$ jacket). The undoubted advantage of these works is the accounting in the models of a stochastic factor of an acting load level on the structure at the moment of strengthening, but, in turn, here, in our opinion, there are also several disadvantages: the imperfect (see above) statistical linearization method is used, as well as, that is more important, the debatable authors statement about structures reliability (without taking into account the random values of permanent and temporary loads, we proceed to the analysis of the structures non-failure rather than their reliability).

\section{Conclusions}

1. As of today, many works are devoted to the study of the impact of aggressive environments on RC structures, the development of probabilistic models of their failures and life cycle, but there are practically no works where there is an analysis of the reliability (including non-failure assessment) of RC structures with mechanical damages of reinforcement or concrete, including under the load action.

2. With the development of the general reliability theory, for the most objective assessment of the $\mathrm{RC}$ structures reliability, there is a need to consider a large number of the random parameters of such systems work. Therefore, in our opinion, the best method to evaluate the non-failure of RC structures is the Monte Carlo method, which is based on the random number generation principle.

\section{References}

System for ensuring the reliability and safety of building objects. General principles of reliability assurance and constructive safety of buildings and structures. DBN V.1.2-14:2018. State Building Codes of Ukraine. (2018). Kyiv: Ministry of Regional Development, Construction and Housing and Communal Service of Ukraine (in Ukrainian). URL:https://uscc.ua/uploads/page/images/normativnye\%20dokumenty/dbn/DBN-V1214-2018.pdf

Eurocode 0. Basis of structural design. EN 1990:2002. European Standart. (2002). Brussels: European Committee for Standardization. URL:https://www.phd.eng.br/wp-content/uploads/2015/12/en.1990.2002.pdf

ISO 2394:2015. General principles on reliability for structures (4th ed.). (2015). ISO. URL:https://www.sis.se/api/ document/preview/918604/

Constructions of buildings and structures. Concrete and reinforced concrete structures. Basic principles. DBN V.2.6-98:2009. State Building Codes of Ukraine. (2011). Kyiv: Ministry of Regional Development and Construction of Ukraine (in Ukrainian). URL: http://interiorfor.com/wp-content/uploads/2017/01/26_98_2009.pdf

Constructions of buildings and structures. Concrete and reinforced concrete structures made of heavy concrete. Design rules. DSTU B V.2.6-156:2010. National Standard of Ukraine. (2011). Kyiv: Ministry of Regional Development and Construction of Ukraine (in Ukrainian). URL: https://dwg.ru/dnl/9603

Voskobiinyk, O. P. (2010). Typological comparison of defects and damages of reinforced concrete, metallic and steel-reinforced concrete beam structures. Bulletin of the Lviv Polytechnic National University. Theory and Building Practice, 662, 97-103 (in Ukrainian). URL: http://ena.lp.edu.ua/bitstream/ntb/6747/1/20.pdf

Klymenko, Ye. V., Antoniuk, N. R., \& Polianskyi, K. V. (2019). Modeling the work of damaged reinforced concrete beams in the SC LIRA-SAPR. Bulletin of the Odessa State Academy of Civil Engineering and Architecture, 77, 58-65 (in Ukrainian). doi:10.31650/2415-377X-2019-77-58-65

Faye, P. N. (2017). Experimental Study on the Degradation Mechanism of RC Structures under Chloride Environment (PhD thesis). URL:https://www.researchgate.net/publication/335433554_Experimental_Study_on_the_ Degradation_Mechanism_of_RC_Structures_under_Chloride_Environment

Khaghanpour, R., Dousti, A., \& Shekarchi, M. (2017). Prediction of Cover Thickness Based on Long-Term Chloride Penetration in a Marine Environment. Journal of Performance of Constructed Facilities, 31(1). doi:10.1061/(ASCE)CF.1943-5509.0000931 
Chen, D., Sun, G., Hu, D., \& Shi, J. (2021). Study on the bearing capacity and chloride ion resistance of RC structures under multi-factor corrosive environment and continuous load. Journal of Building Engineering, 44(6), 102990. doi:10.1016/j.jobe.2021.102990

Sakhno, S. I., Lyulchenko, E. V., Yanova, L. A., \& Pyshchykova, O. V. (2020). Analysis of nonlinear deformations of reinforced concrete beams by the finite element method. Mining Bulletin, 108, 27-34 (in Ukrainian). doi:10.31721/2306-5435-2020-1-108-27-34

Bashynska, O. Yu. (2019). Creation of calculation models of building structures taking into account the rheological properties of reinforced concrete ( $\mathrm{PhD}$ thesis) (in Ukrainian). URL:https://dspace.nau.edu.ua/handle/ NAU/40283

Heraskin, O. O., Rotko, S. V., \& Uzhehova, O. A. (2020). Calculation of a monolithic plate taking into account the rheological properties of reinforced concrete. Modern technologies and methods of calculations in construction, 14, 63-72 (in Ukrainian). doi:10.36910/6775-2410-6208-2020-4(14)-07

Pashinsky, V. V. (2015). Regulation and zoning of the design parameters of air temperature on the territory of Ukraine. Municipal services of cities, 120, 49-53 (in Ukrainian). URL:http://www.irbis-nbuv.gov.ua/cgibin/irbis_nbuv/cgiirbis_64.exe?I21DBN=LINK\&P21DBN=UJRN\&Z21ID=\&S21REF=10\&S21CNR=20\&S21STN $=1 \& S 21 F M T=A S P \_m e t a \& C 21 C O M=S \& 2 \_S 21 P 03=F I L A=\& 2 \_S 21 S T R=k g m \_t e c h \_2015 \_120 \_12$

Kiesse, T. S., Bonnet, S., Amiri, O., \& Ventura, A. (2020). Analysis of corrosion risk due to chloride diffusion for concrete structures in marine environment. Marine Structures, 73, 102804. doi:10.1016/j.marstruc.2020.102804

Pellizzer, G. P., Leonel, E. D., \& Nogueira, C. G. (2015). Influence of reinforcement's corrosion into hyperstatic reinforced concrete beams: a probabilistic failure scenarios analysis. IBRACON Structures and Materials Journal, 8(4), 479-490. doi:10.1590/S1983-41952015000400004

Bastidas-Arteaga, E., Bressolette, P., Chateauneuf, A., \& Sanchez-Silva, M. (2009). Probabilistic lifetime assessment of RC structures under coupled corrosion-fatigue deterioration processes. Structural Safety, 31(1), 8496. doi:10.1016/j.strusafe.2008.04.001

Conciatori, D., Bruhwiler, E., \& Morgenthaler, S. (2009). Calculation of reinforced concrete corrosion initiation probabilities using the Rosenblueth method. International Journal of Reliability and Safety, 3(4). doi:10.1504/IJRS.2009.028581

Krasnoshchekov, Y. V., \& Zapoleva, M. Yu. (2015). Probabilistic design of structures by the given level of reliability. Bulletin of the Siberian State Automobile and Highway Academy, 1(41), 68-73 (in Russian). URL:https://cyberleninka.ru/article/n/veroyatnostnoe-proektirovanie-konstruktsiy-po-zadannomu-urovnyu-nadezhnosti

Khmil, R. Ye., Tytarenko, R. Yu., Blikharskyy, Ya. Z., \& Vegera, P. I. (2021). Improvement of the method of probability evaluation of the failure-free operation of reinforced concrete beams strengthened under load. IOP Conference Series: Materials Science and Engineering, 1021, 012014. doi:10.1088/1757-899X/1021/1/012014

Khmil, R., Tytarenko, R., Blikharskyy, Y., \& Vegera, P. (2021). The Probabilistic Calculation Model of RC Beams, Strengthened by RC Jacket. Lecture Notes in Civil Engineering, 100, 182-191. doi:10.1007/978-3-03057340-9_23

Ventsel, O. S. (2018). Probability theory (12th ed.). Moscow: Justitia (in Russian). URL: https://cdn1.ozone.ru/ multimedia/1020633476.pdf

Р. Ю. Титаренко, Р. Є. Хміль, І. П. Данкевич Національний університет “Львівська політехніка", кафедра будівельних конструкцій та мостів

\section{ТЕОРЕТИЧНИЙ АНАЛІЗ ІСНУЮЧИХ КОНЦЕПЦІЙ ОЦІНЮВАННЯ БЕЗВІДМОВНОСТІ ЗАЛІЗОБЕТОННИХ КОНСТРУКЦІЙ, ЩО ЗНАХОДЯТЬСЯ В ЕКСПЛУАТАЦЇ̈}

() Титаренко Р. Ю., Хміль Р. Є., Данкевич I.П., 2021

Представлено теоретичний аналіз наявних концепцій оцінювання безвідмовності залізобетонних конструкцій, що перебувають в експлуатації. Для проведення аналізу автори розглянули низку наукових праць як українських, так і зарубіжних дослідників. Основну увагу звернуто на роботи, в 
яких модель стохастичної природи роботи залізобетонної конструкції містила випадкові параметри діючих навантажень (постійних й змінних), а також резерв іiі несучої здатності та експлуатаційної придатності (геометричні розміри поперечних перерізів конструктивних елементів, міцнісні та деформаційні характеристики матеріалів тощо). Серед інших, на думку авторів, важливими проблемами для аналізу окремої праці були обсяг статистичної вибірки випадкових параметрів, їхня кількість та вплив на результат дослідження, а також раціональність (за конкретних умов) прийнятого методу розрахунку ймовірності відмови (або безвідмовної роботи) залізобетонної конструкції, що перебуває в експлуатації. На основі опрацювання низки наукових праць, автори виділяють актуальність, переваги та недоліки запропонованих там концепцій оцінювання безвідмовності, а також формулюють висновки та рекомендації щодо подальших експериментально-теоретичних досліджень у цьому напрямі. Крім того, автори виявили, що значний вплив на ймовірність безвідмовної роботи тієї чи іншої залізобетонної конструкції, що перебуває в експлуатації, мають стохастичні параметри змінних кліматичних навантажень (температурного, снігового, вітрового та ожеледного - відповідно до актуальних метеорологічних даних), агресивного середовища (корозія залізобетону), механічних пошкоджень бетону та арматури, а також реологічних властивостей залізобетону як композитного матеріалу. Насамкінець у статті встановлено, що з погляду вдосконалення тих чи інших концепцій оцінювання безвідмовності, чисельне моделювання залізобетонних конструкцій, що перебуває в експлуатації, а також нелінійний розрахунок парметрів їхнього напружено-деформованого стану доцільно виконувати в сучасних ПК (типу ЛІРА-CAПР, ANSYS, SCAD Office, Femap with NX Nastran тощо) методом скінчених елементів.

Ключові слова: оцінка безвідмовності, ймовірність безвідмовної роботи, залізобетон, діюче навантаження на конструкцію, випадковий параметр, статистична вибірка, чисельне моделювання, метод розрахунку, метод Монте-Карло. 